\title{
Multiplexed Microsphere Suspension-Array Assay for Urine Mitochondrial DNA Typing by C-Stretch Length in Hypervariable Regions
}

\author{
Kimiko Aokia, b, c, Hiroyuki Tanaka ${ }^{\mathrm{a}}$, Takashi Kawahara ${ }^{\mathrm{a}}$
}

\begin{abstract}
Background: The standard method for personal identification and verification of urine samples in doping control is short tandem repeat (STR) analysis using nuclear DNA (nDNA). The DNA concentration of urine is very low and decreases under most conditions used for sample storage; therefore, the amount of DNA from cryopreserved urine samples may be insufficient for STR analysis. We aimed to establish a multiplexed assay for urine mitochondrial DNA typing containing only trace amounts of DNA, particularly for Japanese populations.
\end{abstract}

Methods: A multiplexed suspension-array assay using oligo-tagged microspheres (Luminex MagPlex-TAG) was developed to measure C-stretch length in hypervariable region 1 (HV1) and 2 (HV2), five single nucleotide polymorphisms (SNPs), and one polymorphic indel. Based on these SNPs and the indel, the Japanese population can be classified into five major haplogroups (D4, B, M7a, A, D5). The assay was applied to DNA samples from urine cryopreserved for $1-1.5$ years $(n=63)$ and fresh blood $(n=150)$.

Results: The assay with blood DNA enabled Japanese subjects to be categorized into 62 types, exhibiting a discriminatory power of 0.960 . The detection limit for cryopreserved urine was $0.005 \mathrm{ng}$ of nDNA. Profiling of blood and urine pairs revealed that 5 of 63 pairs showed different C-stretch patterns in HV1 or HV2.

Conclusions: The assay described here yields valuable information in terms of the verification of urine sample sources employing only trace amounts of recovered DNA. However, blood cannot be used as a reference sample.

Keywords: Suspension-array assay; MagPlex-TAG microspheres; Mitochondrial DNA; C-stretch length; Hypervariable region; Urine

Manuscript submitted December 12, 2017, accepted April 10, 2018

${ }^{a}$ Anti-doping Research Laboratory, Japan Chemical Analysis Center, 6-39-4, Minami Senju, Arakawa-ku, Tokyo, 116-0003, Japan

bNihon Pharmaceutical University, 10281, Komuro, Inamachi, Kitaadachigun, Saitama 362-0806, Japan

${ }^{c}$ Corresponding Author: Kimiko Aoki, 411 1-14-14 Machiya, Arakawa-ku Tokyo 116-0001, Japan. Email: kimiko-aoki@kxd.biglobe.ne.jp

doi: https://doi.org/10.14740/jocmr3302w sample

\section{Introduction}

Urine samples collected via noninvasive methods are widely used in regulation, control, and monitoring of doping and are cryopreserved for a maximum of 10 years for re-examination. When substitution or manipulation of a urine sample is suspected, the standard method for personal identification and verification of urine samples in doping control is short tandem repeat (STR) analysis using nuclear DNA (nDNA) [1-5]. Urine nDNA concentration is very low and inconsistent [6-11] and decreases under most conditions used for sample preservation [7-13]. The success rate of STR analysis using $10 \mathrm{~mL}$ of unprocessed urine samples cryopreserved for $1-1.5$ years has been reported to be $<100 \%$ [14]. Therefore, a simple assay exhibiting enhanced analytical sensitivity with trace amounts of nDNA has been concluded to be required in doping control.

Mitochondrial DNA (mtDNA) represents an advantageous target for personal identification and verification through its significantly elevated cellular copy number (100 - 1,000-fold compared with a single diploid representation of nDNA, which enables measurements even after prolonged storage). However, one disadvantage of mtDNA analysis is the greatly diminished inter-individual discriminatory capacity due to the maternal mode of inheritance.

The major haplogroups of the mtDNA characteristics of Japanese subjects were reported to be D4, B, M7a, A, and D5 [15], which can be classified by the assessment of five single nucleotide polymorphisms (SNPs; 3010G $>$ A, 4386T $>$ C, 5178C $>$ A, $8794 \mathrm{C}>\mathrm{T}$, and $10397 \mathrm{~A}>\mathrm{G})$ and one deletion $(8272 \mathrm{C}>\mathrm{del})$ [16]. $\mathrm{C}$-stretch length mutation was observed with a high frequency in the hypervariable regions, 16184-16193 (HV1C) and 303-315 (HV2C), of the mtDNA control region [17, 18]. Different HV2C profiles were observed, as a result of not following maternal inheritance, between mother and child [19-21], among siblings $[22,23]$, and among various tissues, including hair shafts from the same individual [24-27]. HV1C and HV2C mutants in cervical cells have been reported to be stable for $10-20$ years in a longitudinal retrospective study [28].

Suspension-array technology (Luminex xMAP) [29] has been applied to a simultaneous detection method of various 
Table 1. PCR Primer Sequences

\begin{tabular}{|c|c|c|c|c|c|}
\hline \multirow{2}{*}{ Target } & \multicolumn{2}{|r|}{ Forward } & \multicolumn{2}{|r|}{ Reverse } & \multirow{2}{*}{$\begin{array}{l}\text { Amplicon } \\
\text { size (bp) }\end{array}$} \\
\hline & Position & Sequence $\left(5^{\prime}\right.$ to $\left.3^{\prime}\right)$ & Position & Sequence (5' to $\left.3^{\prime}\right)$ & \\
\hline \multicolumn{6}{|c|}{ SNP and deletion [30] } \\
\hline $4386 \mathrm{~T}>\mathrm{C}$ & 4344 & TCGAACCCATCCCTGAGAATCC & 4577 & GTTTATTTCTAGGCCTACTCAGGTAA & 234 \\
\hline $5178 \mathrm{C}>\mathrm{A}$ & 4989 & CAGCTACGCAAAATCTTAGCATAC & 5257 & TTGGGCAAAAAGCCGGTTAGCG & 269 \\
\hline $10397 \mathrm{~A}>\mathrm{G}$ & 10277 & ACCCCTACCATGAGCCCTACAA & 10515 & GTGAGATGGTAAATGCTAGTATAATAT & 239 \\
\hline \multicolumn{6}{|l|}{ C-stretch [36] } \\
\hline HV1C & 15896 & CAAATGGGCCTGTCCTTGTA & 16414 & TGTGCGGGATATTGATTTC & 519 \\
\hline $\mathrm{HV} 2 \mathrm{C}$ & 29 & GGTCTATCACCCTATTAACCAC & 408 & CTGTTAAAAGTGCATACCGCCA & 380 \\
\hline
\end{tabular}

SNPs and indels in mtDNA [30-32]. Recently, the construction of a suspension-array assay was simplified using MagPlexTAG microspheres (MagPlex-TAG), which are magnetic, differently-fluorescent beads covalently coupled to unique 24-mer "anti-TAG" oligonucleotide sequences $[33,34]$. The assay with MagPlex-TAG consists of three steps: polymerase chain reaction (PCR), allele-specific primer extension (ASPE), and then hybridization between the ASPE product and MagPlex-TAG.

In this study, we report the development of a multiplexed suspension-array assay using MagPlex-TAG for mtDNA typing by measurement of $\mathrm{C}$-stretch sequences in $\mathrm{HV} 1 \mathrm{C}$ and HV2C as well as analysis of five SNPs and one deletion. The discrimination power and detection limit of the assay were evaluated by its application to blood and urine samples, respectively. In addition, mtDNA profiles in urine and blood pairs were compared to determine whether blood could be used as an appropriate reference sample.

\section{Materials and Methods}

Nucleotide position numbers used are consistent with the revised Cambridge Reference Sequence [35].

\section{Materials}

Streptavidin-R-PE, dGTP, dATP, dTTP, Biotin-dCTP, and Fast SYBR $^{\circledR}$ Green Master Mix were purchased from Life Technologies Japan (Tokyo, Japan); ExoSAP-IT ${ }^{\circledR}$ from Affymetrix (Cleveland, Ohio, USA); Puregene ${ }^{\circledR}$ Blood Core kit and HotStar Taq ${ }^{\circledR}$ Master Mix kit from QIAGEN (Hilden, Germany); NucleoSpin ${ }^{\circledR}$ gDNA Clean-up and NucleoSpin ${ }^{\circledR}$ gDNA Cleanup XS kits from Macherey-Nagel (Duren, Germany); Novagen ${ }^{\circledR}$ human gDNA from Merck (Darmstadt, Germany); TaKaRa Taq ${ }^{\text {TM }}$ Hot Start version from Takara Bio (Shiga, Japan); and MagPlex ${ }^{\circledR}-$ TAG microspheres from Luminex Japan (Tokyo, Japan). D17Z1 primers were synthesized by Life Technologies Japan, and mtDNA-specific PCR primers and ASPE primers by Integrated DNA Technologies (Austin, Texas, USA). All other chemicals and solvents were of the highest quality commercially available.

\section{Samples and DNA extraction}

This study was reviewed and approved by the Review Board of the Japan Chemical Analysis Center, Anti-doping Research Laboratory. Permission was granted to use materials collected solely for research study. Japanese males aged 20 - 35 years, who were recruited from outside our laboratory, provided informed consent.

Urine and blood samples were collected at the Yanagibashi-Clinical Trial Center (Tokyo, Japan) in January 2011, following confirmation that these subjects were negative for HIV and hepatitis B and C. DNA (nDNA and mtDNA) was extracted as previously described [14]. Briefly, DNA was extracted both from urine cryopreserved for $1-1.5$ years (hereafter referred to as cryopreserved urine) and fresh blood using the Puregene Blood Core kit. Extracted urine DNA was purified with a NucleoSpin gDNA Clean-up kit or NucleoSpin gDNA Clean-up XS kit. DNA samples from cryopreserved urine (n $=63)$ and fresh blood $(\mathrm{n}=150)$ were stored at $-20{ }^{\circ} \mathrm{C}$ and 4 ${ }^{\circ} \mathrm{C}$, respectively, until use. Due to the difficulty of quantifying mtDNA, DNA quantity was determined using the nDNA quantitative value rather than mtDNA.

\section{Multiplexed suspension-array assay with MagPlex-TAG}

The assay was established following the manufacturer's protocols [33] and modified to achieve appropriate sensitivity. The 
Table 2. ASPE Primer Sequences for Detection of Five SNPs and One Deletion in MtDNA

\begin{tabular}{|c|c|}
\hline & Sequence $\left(5^{\prime}\right.$ to $\left.3^{\prime}\right)$ \\
\hline \multirow[t]{2}{*}{$3010 \mathrm{G}>\mathrm{A}$} & (CTATCATTTATCTCTTTCTCAATT) ATGTTGGATCAGGACATCCCG \\
\hline & (CAATAAACATTCTTTACATTCTCA) GATGTTGGATCAGGACATCCCA \\
\hline $4386 \mathrm{~T}>\mathrm{C}$ & (CATAATCAATTTCAACTTTCTACT) CTTACTTTAGGATGGGGTGTGC \\
\hline $5178 \mathrm{C}>\mathrm{A}$ & (ATTAAACAACTCTTAACTACACAA) TATCTCGCACCTGAAACAAGC \\
\hline $8272 \mathrm{C}>\mathrm{del}$ & (CATCTTCATATCAATTCTCTTATT) CCCTATAGCACCCССТCTAG \\
\hline \multirow[t]{2}{*}{$8794 \mathrm{C}>\mathrm{T}$} & (TTAATACAATTCTCTCTTTCTCTA) TGGGTGGTTGGTGTAAATGAGTG \\
\hline & (AACTTTCTCTCTCTATTCTTATTT) TGGGTGGTTGGTGTAAATGAGTA \\
\hline $10397 \mathrm{~A}>\mathrm{G}$ & (TTAACAACTTATACAAACACAAAC) TGACTACAAAAAGGATTAGACTGA \\
\hline
\end{tabular}

Sequences in parentheses indicate 24-mer TAG sequences.

Applied Biosystems Veriti Thermal Cycler (Life Technologies, Japan) was used with 8-tube PCR strips (0.2 mL) for PCR, ExoSAP-IT treatment, and ASPE, and with 96-well PCR plates $(0.1 \mathrm{~mL})$ for hybridization.

\section{Multiplexed PCR}

Multiplexed PCR was performed in a total volume of $20 \mu \mathrm{L}$ with HotStar Taq Master Mix $(10 \mu \mathrm{L}, 1$ unit HotStar Taq DNA Polymerase in PCR buffer with $3 \mathrm{mM} \mathrm{MgCl}_{2}$, and $400 \mu \mathrm{M}$ of each deoxynucleotide (dNTP)), $200 \mathrm{nM}$ each of 8-primer pair (Table 1) [30, 36], and a DNA sample solution. Thermal cycling conditions were $95^{\circ} \mathrm{C}$ for $10 \mathrm{~min} ; 35$ cycles of $94^{\circ} \mathrm{C}$ for $30 \mathrm{~s}, 55^{\circ} \mathrm{C}$ for $30 \mathrm{~s}$, and $72^{\circ} \mathrm{C}$ for $1 \mathrm{~min}$; and $72^{\circ} \mathrm{C}$ for $10 \mathrm{~min}$. The sizes of amplified products were confirmed by electrophoresis on $2 \%$ agarose gels in preliminary experiments.

Unincorporated PCR primers and dNTPs were removed from the reaction mixture after PCR by treatment with $3.5 \mu \mathrm{L}$ of ExoSAP-IT at $37^{\circ} \mathrm{C}$ for $30 \mathrm{~min}$ or $90 \mathrm{~min}$, followed by incubation at $80^{\circ} \mathrm{C}$ for $15 \mathrm{~min}$.

\section{Multiplexed ASPE}

ASPE primers were designed to flank the targeted base at the 3' ends and a TAG sequence (24-mer) at the $5^{\prime}$ termini. Sequences with melting temperatures $(\mathrm{Tm})$ between $51^{\circ} \mathrm{C}-56^{\circ} \mathrm{C}$ were selected from 18 -24-mer sequences with the targeted base at the $3^{\prime}$ ends [33]. Tm of the sequences was calculated using the Oligonucleotide Properties Calculator (http://www.basic. northwestern.edu/biotools/oligocalc.html). A TAG sequence suitable for the selected sequence and the corresponding MagPlex-TAG were selected on advice provided by Luminex.

Two ASPE primers targeting each wild-type and mutant base were prepared for five SNPs and one deletion (Table 2). C-stretch sequences [18] were classified into nine groups for $\mathrm{HV} 1 \mathrm{C}$ and six groups for $\mathrm{HV} 2 \mathrm{C}$ according to the number of $\mathrm{C}$ before $\mathrm{T}$ or the absence of $\mathrm{T}$ in these regions. An ASPE primer was prepared for each group (Tables 3,4). A total of 27 ASPE primers were used, of which 10 are for five SNPs, two for the deletion, nine for $\mathrm{HV} 1 \mathrm{C}$, and six for $\mathrm{HV} 2 \mathrm{C}$.

Multiplexed ASPE was conducted in $30 \mu \mathrm{L}$ of PCR buffer (10 mM Tris- $\mathrm{HCl}, \mathrm{pH} 8.3,50 \mathrm{mM} \mathrm{KCl}$, and $1.5 \mathrm{mM} \mathrm{MgCl}_{2}$ ) containing $5 \mu \mathrm{M}$ each of dATP, dTTP, dGTP, and biotin-dCTP, $1.125 \mathrm{U}$ of TaKaRa Taq Hot Start DNA polymerase, $25 \mathrm{nM}$ of each 27 ASPE primers and $7.5 \mu \mathrm{L}$ of ExoSAP-IT-treated PCR products. Thermal cycling conditions were 32 cycles of $94^{\circ} \mathrm{C}$ for $30 \mathrm{~s}, 55^{\circ} \mathrm{C}$ for $30 \mathrm{~s}$, and $72^{\circ} \mathrm{C}$ for $1 \mathrm{~min}$.

\section{Hybridization}

Overall, 10 or $25 \mu \mathrm{L}$ of ASPE products was hybridized with 2,000 particles of each of the 27 different MagPlex-TAGs in $50 \mu \mathrm{L}$ of hybridization buffer $(\mathrm{HB}, 0.1 \mathrm{M}$ Tris- $\mathrm{HCl}, \mathrm{pH} 8.0$, containing $0.2 \mathrm{M} \mathrm{NaCl}$ and $0.08 \%$ Triton $\mathrm{X}-100)$. The mixtures were incubated at $96{ }^{\circ} \mathrm{C}$ for $90 \mathrm{~s}$ followed by $37^{\circ} \mathrm{C}$ for $30 \mathrm{~min}$. After washing twice using a 96-well magnet plate, the hybridized MagPlex-TAGs were incubated with $75 \mu \mathrm{L}$ of $\mathrm{HB}$ containing streptavidin-R-PE $(2 \mu \mathrm{g} / \mathrm{mL})$ at $37{ }^{\circ} \mathrm{C}$ for 15 min. PE fluorescence of $50 \mu \mathrm{L}$ of the mixture was measured as units of Median Fluorescence Intensity (MFI) at $37^{\circ} \mathrm{C}$ for a maximum of $200 \mathrm{~s}$ using a Luminex 200 analyzer (Austin, TX, USA) with the associated software (xPONENT ${ }^{\circledR}$ ). Haplogroups were defined as A for 8794T, B for 8272del, D4 for 3010A and 5178A, D5 for 5178A and 10397G, and M7a for 4386C. A C-stretch pattern composed of more than two groups was expressed in descending order of MFI of the group.

\section{Discrimination power of the assay}

Blood DNA samples containing approximately $5 \mathrm{ng}$ of nDNA were assayed under the same conditions as for ExoSAP-IT, with a treatment time of $30 \mathrm{~min}$, and an ASPE product volume 
Table 3. ASPE Primer Sequences for Detection of HV1C Groups in MtDNA

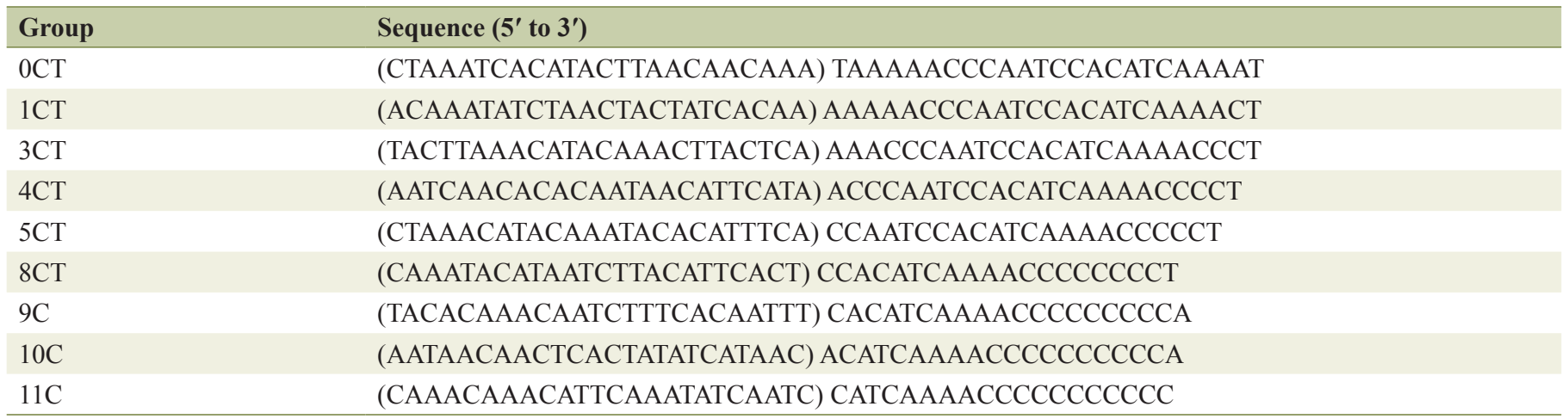

Sequences in parentheses indicate 24-mer TAG sequences. Position at 16194 is A.

used for hybridization of $10 \mu \mathrm{L}(\mathrm{n}=150)$. A positive result was defined as a value greater than four times the MFI obtained from the corresponding negative control. Discrimination power was calculated using the Discriminatory Power Calculator (http://insilico.ehu.es/mini_tools/discriminatory_power/index. php).

\section{Detection limit of the assay for cryopreserved urine}

Cryopreserved urine DNA samples containing $<0.15 \mathrm{ng}$ of nDNA were assayed under the same conditions as for ExoSAP-IT, with a treatment time of $90 \mathrm{~min}$, and an ASPE product volume used for hybridization of $25 \mu \mathrm{L}$. A positive result was defined as a value greater than two times the MFI obtained from the corresponding negative control.

Urine DNA samples containing 0.1 or $0.03 \mathrm{ng}$ of $\mathrm{nDNA}$ were diluted to $0.005,0.0025$, and $0.00125 \mathrm{ng}(\mathrm{n}=10)$. The lowest DNA quantity displaying the same mtDNA type as that for 0.1 or $0.03 \mathrm{ng}$ was judged to be the detection limit.

\section{Quantification of nDNA}

Real-time PCR was performed using the Applied Biosystems ViiA 7 system (Life Technologies Japan) with Fast SYBR Green Master Mix containing $200 \mathrm{nM}$ each of nDNA-specific D17Z1 primers (Table 1) [37] and $1 \mu \mathrm{L}$ of standard human gDNA $(0.0012-12 \mathrm{ng} / \mu \mathrm{L})$ or DNA solution in a final volume of $15 \mu \mathrm{L}$, as previously described [14].

\section{MtDNA quantity of cryopreserved urine relative to blood}

DNA samples, diluted serially four times $(1 \mu \mathrm{L})$, were amplified with $200 \mathrm{nM}$ each of mtDNA-specific NADH-ubiquinone oxidoreductase chain 1 (ND1) primers (Table 1) [38] under the same conditions as for nDNA quantification to obtain $\mathrm{Ct}$ values. Separately, the nDNA quantities of the serially diluted DNA samples were measured as described above. The Y-axis intercept of an approximately straight line from the scatter plot of the $\mathrm{Ct}$ values of ND1 and the logarithm of nDNA quantities, $\mathrm{Ct}$ value of ND1/nDNA (1 ng), was obtained using Microsoft Excel 2010 tool. The Ct values of ND1/nDNA (1 ng) of urine and blood are referred to as $\mathrm{Ct}_{\text {urine }}$ and $\mathrm{Ct}_{\text {blood }}$, respectively. The mtDNA quantity of cryopreserved urine $(n=5)$ relative to blood $(\mathrm{n}=5)$ was calculated from the equation $2^{\Delta \mathrm{Ct}}(\Delta \mathrm{Ct}=\mathrm{Ct}$ blood $\left.-\mathrm{Ct}_{\text {urine }}\right)$. Results were expressed as mean $\pm \mathrm{SD}$. Statistical analysis was performed using the Mann-Whitney U test, with $\mathrm{P}<0.05$ regarded as significant.

\section{Results}

\section{Discrimination power of the assay}

Japanese subjects $(n=150)$ were classified into 62 types con-

Table 4. ASPE Primer Sequences for Detection of HV2C Groups in MtDNA

\begin{tabular}{ll}
\hline Group & Sequence $\left(\mathbf{5}^{\prime}\right.$ to $\mathbf{3}^{\prime}$ ) \\
\hline $6 \mathrm{CT}$ & (TCTCTTTAAACACATTCAACAATA) AAAAAATTTCCACCAAACCCCCCT \\
$7 \mathrm{CT}$ & (CTTTCTTAATACATTACAACATAC) AAAATTTCCACCAAACCCCCCCT \\
$8 \mathrm{CT}$ & (CAATTTACATTTCACTTTCTTATC) TTTCCACCAAACCCCCCCCT \\
$9 \mathrm{CT}$ & (CATAAATCTTCTCATTCTAACAAA) CCACCAAACCCCCCCCCT \\
$11 \mathrm{C}$ & (TACAACATCTCATTAACATATACA) ACCAAACCCCCCCCCCCG \\
$13 \mathrm{C}$ & (AATCTCTACAATTTCTCTCTAATA) ACCAAACCCCCCCCCCCC \\
\hline
\end{tabular}

Sequences in parentheses indicate 24-mer TAG sequences. Position at 316 is G. 
sisting of a combination of C-stretch patterns of HV1C and HV2C and the major haplogroups of Japanese populations by blood DNA analysis (Table 5). Type 5CT $>10 \mathrm{C}(\mathrm{HV} 1 \mathrm{C}) / 7 \mathrm{CT}$ $(\mathrm{HV} 2 \mathrm{C}) / \mathrm{D} 4$ was identified as representing the highest frequency $(20 / 150,13.3 \%)$. The discrimination power of the assay was determined to be 0.960 .

Haplogroup frequencies were $37.3 \%$ for D4, $10.7 \%$ for B, $9.3 \%$ for $\mathrm{M} 7 \mathrm{a}, 7.3 \%$ for A, $3.3 \%$ for $\mathrm{D} 5$, and $32.0 \%$ for "others" (Table 5). There were 15 patterns, including $2.0 \%$ of "others" identified for HV1C (Table 6). The frequency of patterns consisting of one, two, or three groups was $10.7 \%, 57.3 \%$, or $30.0 \%$, respectively. Pattern 5CT $>10 \mathrm{C}$ was the most frequent pattern observed (48.7\%), followed by $10 \mathrm{C}>11 \mathrm{C}>9 \mathrm{C}(22.0 \%)$. A particular pattern was related to a particular haplogroup. The frequencies of $5 \mathrm{CT}>10 \mathrm{C}$ in $\mathrm{D} 4$ and $\mathrm{M} 7 \mathrm{a}$ were $76.8 \%(43 / 56)$ and $71.4 \%(10 / 14)$, respectively. Furthermore, all patterns in B haplogroup were composed of 9C, 10C, and/or 11C. The discriminatory power of the assay that incorporated HV1C typing and haplotyping was 0.884 .

There were 12 patterns, including $8.7 \%$ of "others" identified for HV2C (Table 7). The frequency of patterns consisting of one or two groups was $74.7 \%$ or $16.7 \%$, respectively. Patterns 7CT and 8CT displayed similar high frequencies of $36.7 \%$ and $37.3 \%$, respectively. As a result, $89.3 \%$ of Japanese subjects showed $7 \mathrm{CT}$ or/and $8 \mathrm{CT}$. There was no particular pattern related to a particular haplogroup with $>70 \%$ frequency. The discrimination power of the assay that incorporated HV2C typing and haplotyping was 0.917.

\section{Comparison of mtDNA type between urine and blood}

MtDNA types of cryopreserved urine samples were compared with those of the corresponding blood samples ( $\mathrm{n}=63$ pairs). Haplogroups of urine and blood were completely matched in all 63 pairs. However, C-stretch patterns were different in 18 pairs. The difference in 13 pairs resulted from the presence or absence of the group with the lowest MFI, a value near the defined positive and negative boundaries (Table 8). The remaining 5 pairs showed a difference in the MFI order of the same composing groups (Table 9). All patterns showing differences in $\mathrm{HV} 1 \mathrm{C}$ consisted of three poly $\mathrm{C}$-sequences $(9 \mathrm{C}, 10 \mathrm{C}$, and 11C). In particular, all urine samples corresponding to blood samples with $11 \mathrm{C}>10 \mathrm{C}>9 \mathrm{C}$ showed patterns different from blood. One pair showed a difference in $\mathrm{HV} 2 \mathrm{C}$ pattern consisting of $6 \mathrm{CT}$ and $7 \mathrm{CT}$. $10 \mathrm{C}>9 \mathrm{C}>11 \mathrm{C}$ (HV1C) and $7 \mathrm{CT}>6 \mathrm{CT}$ (HV2C) in urine were patterns not found in any of 150 blood samples (Tables 5-7).

\section{Detection limit of the assay with MagPlex-TAG for cryo- preserved urine}

$\mathrm{Ct}_{\text {urine }}$ and $\mathrm{Ct}_{\text {blood }}$ values were $17.7 \pm 0.5$ and $21.0 \pm 0.4$, respectively $(\mathrm{P}<0.05)$. MtDNA quantity of cryopreserved urine relative to blood calculated from $2^{\Delta \mathrm{Ct}}$, in which $\Delta \mathrm{Ct}=\mathrm{Ct}_{\text {blood }}$ - $\mathrm{Ct}_{\text {urine }}=3.3$, was 9.85. The result indicated that the mtDNA quantity was approximately 10 times more in cryopreserved urine than in blood, when both nDNA quantities were the same.

Analysis of DNA from cryopreserved urine samples revealed that the lowest nDNA quantity displaying the same mtDNA type as that derived from nDNA ( 0.1 or $0.03 \mathrm{ng})$ was 0.0025 or $0.005 \mathrm{ng}$ (Table 10 ). We concluded that the detection limit of the assay was $0.005 \mathrm{ng}$ when cryopreserved urine samples were used.

\section{Discussion}

We established a multiplexed suspension-array assay employing MagPlex-TAG for Japanese populations in which Cstretch length mutations in $\mathrm{HV} 1 \mathrm{C}$ and $\mathrm{HV} 2 \mathrm{C}$ as well as five SNPs and one deletion in mtDNA could be identified. Using a combination of two C-stretch typings and major haplotyping, Japanese subjects $(n=150)$ were classified into 62 types by blood DNA analysis. The discriminatory power of the assay was 0.960 . The detection limit of the assay was $0.005 \mathrm{ng}$ when DNA from cryopreserved urine samples was used. Our assay represents a potential method for the personal identification or verification of urine sample contributors containing only trace amounts of DNA following long-term cryopreservation in doping control.

According to the established assay, Japanese subjects were classified into 62 types combining six haplogroups, 15 HV1C patterns, and $12 \mathrm{HV} 2 \mathrm{C}$ patterns. Our haplogroup frequencies were consistent with results from 1,312 Japanese individuals: D4 (32.6\%), B (13.3\%), M7a (7.5\%), A (6.9\%), D5 (4.8\%), and "others" (34.9\%) [15]. Currently, there are no reports of $\mathrm{C}$-stretch patterns consisting of multiple groups in Japanese populations. Therefore, the frequencies of patterns with $5 \mathrm{CT}$ (HV1C) or 8CT (HV2C) as the main group were summed to compare with previously published findings provided by direct sequencing $[18,39]$. The calculated frequencies, $56.7 \%$ (5CT) and $48.7 \%(8 \mathrm{CT})$, were close to the results of previous reports of $58.6 \%$ and $45.0 \%$ [ 18 ] and $62.6 \%$ and $40.8 \%$ [39]. Although we have not confirmed $\mathrm{C}$-stretch patterns by other methods, these results demonstrated that our assay seems to exhibit high reliability in $\mathrm{C}$-stretch typing.

HV2C typing contributed more to improving the discriminatory power of this assay involving haplotyping than HV1C characterization. The basis of this observation is likely to be the strong relation between an HV1C pattern and D4, M7a or B haplogroups. Our results that all HV1C patterns of B haplogroup consist only of groups with $16189 \mathrm{C}(9 \mathrm{C}, 10 \mathrm{C}, 11 \mathrm{C})$ were consistent with the coexistence of $16189 \mathrm{C}$ with B haplogroup in Asian, African, Nicobarese, and Indonesian populations [40, 41]. The existence of a strong relation between HV1C pattern and haplogroup impeded the improvement of the discriminatory power of the assay.

There were two types of differences in C-stretch pattern observed between urine and the corresponding blood in some subjects. The first was different due to absence of the group with the lowest MFI in the pattern consisting of groups showing the same MFI order (Table 8). Except for one case showing $8 \mathrm{CT} \leftrightarrow$ other, the lowest MFI value was near the defined positive and negative boundaries, even when the group was 
Table 5. Frequency of Type Consisting of HV1C Pattern, HV2C Pattern, and Major Haplogroups for Japanese Populations

\begin{tabular}{|c|c|c|c|c|c|c|c|c|}
\hline HV1C & HV2C & $\mathbf{A}$ & B & D4 & D5 & M7a & Others & Frequency N (\%) \\
\hline $0 \mathrm{CT}$ & $8 \mathrm{CT}$ & & & & & & 1 & $1(0.7)$ \\
\hline \multirow[t]{3}{*}{$3 \mathrm{CT}$} & $7 \mathrm{CT}$ & 2 & & 1 & & & & $3(2.0)$ \\
\hline & $8 \mathrm{CT}$ & 4 & & & & & & $4(2.7)$ \\
\hline & $8 \mathrm{CT}>9 \mathrm{CT}$ & 1 & & & & & & $1(0.7)$ \\
\hline \multirow[t]{3}{*}{$5 \mathrm{CT}$} & $7 \mathrm{CT}$ & & & & & & 1 & $1(0.7)$ \\
\hline & $8 \mathrm{CT}$ & & & 2 & & & & $2(1.3)$ \\
\hline & Others & & & 1 & & & & $1(0.7)$ \\
\hline $10 \mathrm{C}$ & $7 \mathrm{CT}$ & & & & & & 1 & $1(0.7)$ \\
\hline \multirow[t]{2}{*}{$11 \mathrm{C}$} & $8 \mathrm{CT}>7 \mathrm{CT}$ & & & & & & 1 & $1(0.7)$ \\
\hline & $13 \mathrm{C}>11 \mathrm{C}$ & & 1 & & & & & $1(0.7)$ \\
\hline $3 \mathrm{CT}>4 \mathrm{CT}$ & $9 \mathrm{CT}>8 \mathrm{CT}$ & & & & & & 1 & $1(0.7)$ \\
\hline $5 \mathrm{CT}>8 \mathrm{CT}$ & $7 \mathrm{CT}$ & & & 1 & & & & $1(0.7)$ \\
\hline \multirow[t]{7}{*}{$5 \mathrm{CT}>10 \mathrm{C}$} & $7 \mathrm{CT}$ & & & 20 & & 4 & 6 & $30(20.0)$ \\
\hline & $8 \mathrm{CT}$ & 2 & & 15 & & 2 & 10 & $29(19.3)$ \\
\hline & $7 \mathrm{CT}>8 \mathrm{CT}$ & 1 & & & & & & $1(0.7)$ \\
\hline & $8 \mathrm{CT}>7 \mathrm{CT}$ & & & 6 & & 1 & & $7(4.7)$ \\
\hline & $8 \mathrm{CT}>9 \mathrm{CT}$ & & & & & 2 & & $2(1.3)$ \\
\hline & $9 \mathrm{CT}>8 \mathrm{CT}$ & & & 1 & & & 1 & $2(1.3)$ \\
\hline & Others & & & 1 & & 1 & & $2(1.3)$ \\
\hline \multirow[t]{2}{*}{$10 \mathrm{C}>5 \mathrm{CT}$} & $8 \mathrm{CT}$ & & & & & & 2 & $2(1.3)$ \\
\hline & $8 \mathrm{CT}>7 \mathrm{CT}$ & & & 1 & & & & $1(0.7)$ \\
\hline \multirow[t]{3}{*}{$10 \mathrm{C}>11 \mathrm{C}$} & $6 \mathrm{CT}$ & & & & 1 & & & $1(0.7)$ \\
\hline & $8 \mathrm{CT}$ & & 1 & & 1 & & 1 & $3(2.0)$ \\
\hline & Others & & 2 & & & & 2 & $4(2.7)$ \\
\hline \multirow[t]{3}{*}{$5 \mathrm{CT}>10 \mathrm{C}>9 \mathrm{C}$} & $7 \mathrm{CT}$ & & & 1 & & 1 & 1 & $3(2.0)$ \\
\hline & $8 \mathrm{CT}>7 \mathrm{CT}$ & & & 1 & & 2 & & $3(2.0)$ \\
\hline & $8 \mathrm{CT}>9 \mathrm{CT}$ & & & 1 & & & & $1(0.7)$ \\
\hline $10 \mathrm{C}>3 \mathrm{CT}>9 \mathrm{C}$ & $8 \mathrm{CT}$ & 1 & & & & & & $1(0.7)$ \\
\hline \multirow[t]{6}{*}{$10 \mathrm{C}>11 \mathrm{C}>9 \mathrm{C}$} & $7 \mathrm{CT}$ & & 1 & 2 & & 1 & 9 & $13(8.7)$ \\
\hline & $8 \mathrm{CT}$ & & 5 & 2 & 1 & & 4 & $12(8.0)$ \\
\hline & $6 \mathrm{CT}>7 \mathrm{CT}$ & & & & 1 & & & $1(0.7)$ \\
\hline & $7 \mathrm{CT}>13 \mathrm{C}$ & & 1 & & & & & $1(0.7)$ \\
\hline & $8 \mathrm{CT}>7 \mathrm{CT}$ & & & & & & 1 & $1(0.7)$ \\
\hline & Others & & 3 & & & & 2 & $5(3.3)$ \\
\hline \multirow[t]{4}{*}{$11 \mathrm{C}>10 \mathrm{C}>9 \mathrm{C}$} & $7 \mathrm{CT}$ & & 1 & & & & & $1(0.7)$ \\
\hline & $8 \mathrm{CT}$ & & 1 & & & & & $1(0.7)$ \\
\hline & $13 \mathrm{C}>9 \mathrm{CT}$ & & & & & & 1 & $1(0.7)$ \\
\hline & Others & & & & & & 1 & $1(0.7)$ \\
\hline \multirow[t]{4}{*}{ Others } & $7 \mathrm{CT}$ & & & & & & 2 & $2(1.3)$ \\
\hline & $8 \mathrm{CT}$ & & & & 1 & & & $1(0.7)$ \\
\hline & $\mathrm{N}$ & 11 & 16 & 56 & 5 & 14 & 48 & 150 \\
\hline & $\%$ & 7.3 & 10.7 & 37.3 & 3.3 & 9.3 & 32.0 & \\
\hline
\end{tabular}


Table 6. Frequency of HV1C Pattern in the Major Haplogroups for Japanese Populations

\begin{tabular}{|c|c|c|c|c|c|c|c|}
\hline HV1C & A & B & D4 & D5 & M7a & Others & Frequency $\mathrm{N}(\%)$ \\
\hline 0CT & & & & & & 1 & $1(0.7)$ \\
\hline $3 \mathrm{CT}$ & 7 & & 1 & & & & $8(5.3)$ \\
\hline $5 \mathrm{CT}$ & & & 3 & & & 1 & $4(2.7)$ \\
\hline $10 \mathrm{C}$ & & & & & & 1 & $1(0.7)$ \\
\hline $11 \mathrm{C}$ & & 1 & & & & 1 & $2(1.3)$ \\
\hline $3 \mathrm{CT}>4 \mathrm{CT}$ & & & & & & 1 & $1(0.7)$ \\
\hline $5 \mathrm{CT}>8 \mathrm{CT}$ & & & 1 & & & & $1(0.7)$ \\
\hline $5 \mathrm{CT}>10 \mathrm{C}$ & 3 & & 43 & & 10 & 17 & $73(48.7)$ \\
\hline $10 \mathrm{C}>5 \mathrm{CT}$ & & & 1 & & & 2 & $3(2.0)$ \\
\hline $10 \mathrm{C}>11 \mathrm{C}$ & & 3 & & 2 & & 3 & $8(5.3)$ \\
\hline $5 \mathrm{CT}>10 \mathrm{C}>9 \mathrm{C}$ & & & 3 & & 3 & 1 & $7(4.7)$ \\
\hline $10 \mathrm{C}>3 \mathrm{CT}>9 \mathrm{C}$ & 1 & & & & & & $1(0.7)$ \\
\hline $10 \mathrm{C}>11 \mathrm{C}>9 \mathrm{C}$ & & 10 & 4 & 2 & 1 & 16 & $33(22.0)$ \\
\hline $11 C>10 C>9 C$ & & 2 & & & & 2 & $4(2.7)$ \\
\hline Others & & & & 1 & & 2 & $3(2.0)$ \\
\hline
\end{tabular}

Table 7. Frequency of HV2C Pattern in the Major Haplogroups for Japanese Populations

\begin{tabular}{llllllll}
\hline HV2C & A & B & D4 & D5 & M7a & Others & Frequency N (\%) \\
\hline $6 \mathrm{CT}$ & & & & 1 & & & $1(0.7)$ \\
$7 \mathrm{CT}$ & 2 & 2 & 25 & & 6 & 20 & $55(36.7)$ \\
$8 \mathrm{CT}$ & 7 & 7 & 19 & 3 & 2 & 18 & $56(37.3)$ \\
$6 \mathrm{CT}>7 \mathrm{CT}$ & & & & 1 & & & $1(0.7)$ \\
$7 \mathrm{CT}>8 \mathrm{CT}$ & 1 & & & & & & $1(0.7)$ \\
$8 \mathrm{CT}>7 \mathrm{CT}$ & & & 8 & & 3 & 2 & $13(8.7)$ \\
$7 \mathrm{CT}>13 \mathrm{C}$ & 1 & & 1 & & 2 & & $1(0.7)$ \\
$8 \mathrm{CT}>9 \mathrm{CT}$ & & & 1 & & & 2 & $3(2.7)$ \\
$9 \mathrm{CT}>8 \mathrm{CT}$ & & & & & & 1 & $1(0.7)$ \\
$13 \mathrm{C}>9 \mathrm{CT}$ & & 1 & & & & & $1(0.7)$ \\
$13 \mathrm{C}>11 \mathrm{C}$ & & 5 & 2 & & 1 & 5 & $13(8.7)$ \\
\hline Others & & & & & & & \\
\hline
\end{tabular}

Table 8. Differences in C-stretch Patterns Between 13 Pairs of Urine and Blood Samples

\begin{tabular}{|c|c|c|c|c|}
\hline \multirow{2}{*}{$\mathbf{N}$} & \multicolumn{2}{|c|}{ HV1C } & \multicolumn{2}{|c|}{ HV2C } \\
\hline & Urine & Blood & Urine & Blood \\
\hline 1 & $0 \mathrm{CT}>5 \mathrm{CT}$ & $0 \mathrm{CT}$ & & \\
\hline 2 & $5 \mathrm{CT}>10 \mathrm{C}$ & $5 \mathrm{CT}$ & & \\
\hline 1 & $5 \mathrm{CT}>10 \mathrm{C}$ & $5 \mathrm{CT}>10 \mathrm{C}>9 \mathrm{C}$ & $8 \mathrm{CT}$ & $8 \mathrm{CT}>7 \mathrm{CT}$ \\
\hline 1 & $10 \mathrm{C}>11 \mathrm{C}$ & $10 \mathrm{C}>11 \mathrm{C}>9 \mathrm{C}$ & & \\
\hline 1 & $10 \mathrm{C}>11 \mathrm{C}>9 \mathrm{C}$ & $10 \mathrm{C}>11 \mathrm{C}$ & & \\
\hline 1 & $10 \mathrm{C}>11 \mathrm{C}>9 \mathrm{C}$ & $10 \mathrm{C}>11 \mathrm{C}$ & $6 \mathrm{CT}>7 \mathrm{CT}$ & $6 \mathrm{CT}$ \\
\hline 1 & $11 \mathrm{C}$ & Others & & \\
\hline 1 & & & $7 \mathrm{CT}$ & $7 \mathrm{CT}>13 \mathrm{C}$ \\
\hline 2 & & & $8 \mathrm{CT}$ & $8 \mathrm{CT}>7 \mathrm{CT}$ \\
\hline 1 & & & $8 \mathrm{CT}>7 \mathrm{CT}$ & $8 \mathrm{CT}$ \\
\hline 1 & & & $8 \mathrm{CT}$ & Others \\
\hline
\end{tabular}


Table 9. Differences in C-stretch Patterns Between 5 Pairs of Urine And Blood Samples

\begin{tabular}{llllll}
\hline & & HV1C & & HV2C \\
\cline { 2 - 3 } & Urine & Blood & Urine & Blood \\
\hline 2 & $10 \mathrm{C}>11 \mathrm{C}>9 \mathrm{C}$ & $11 \mathrm{C}>10 \mathrm{C}>9 \mathrm{C}$ & & \\
1 & $10 \mathrm{C}>9 \mathrm{C}>11 \mathrm{C}$ & $11 \mathrm{C}>10 \mathrm{C}>9 \mathrm{C}$ & & \\
1 & $10 \mathrm{C}>9 \mathrm{C}>11 \mathrm{C}$ & $10 \mathrm{C}>11 \mathrm{C}>9 \mathrm{C}$ & & $6 \mathrm{CT}>7 \mathrm{CT}$ \\
\hline
\end{tabular}

determined as negative, it could be distinguish from the other negative groups. The second was due to a different MFI order in the same composing groups. This type of difference was only observed in HV1C pattern consisting of 9C, 10C, and $11 \mathrm{C}$ as well as HV2C pattern consisting of 6CT and 7CT, in which there were patterns present only in urine but not in blood. These results indicated that blood cannot be used as a reference sample in our assay for the personal identity validation of urine samples.

The detection limit of $0.005 \mathrm{ng}$ for cryopreserved urine samples was considerably less than the quantity of nDNA necessary for successful STR analysis (0.6 ng) [14]. An approximately 10 times higher ratio of $\mathrm{mtDNA} / \mathrm{nDNA}$ in cryopreserved urine than in blood was believed to arise from the relatively diminished stability of nDNA under the preservation conditions of urine samples [7-13]. This apparent robustness of mtDNA in cryopreserved urine samples allowed the measurement of two C-stretch sequences and major haplogroups for Japanese populations at lower nDNA concentrations.

In conclusion, this study demonstrated that C-stretch typing, in addition to haplotyping, of samples containing only trace amounts of DNA was possible by a multiplexed suspension-array assay using MagPlex-TAG. Our assay can provide valuable information to ensure the authenticity of urine samples. However, confirmation of the long-term stability of the $\mathrm{C}$-stretch sequence is required for our assay to be adopted in doping control. An advantage of our assay is the ease of introduction of new polymorphic targets of mtDNA, because a maximum of 80 types of MagPlex-TAG are commercially available. Therefore, we intend to develop a more comprehen- sive C-stretch sequence assay to obtain useful knowledge on the lifetime stability of $\mathrm{C}$-stretch sequences in various samples.

\section{Acknowledgments}

The authors acknowledge the valuable support of Ms. Fujiko Sekine from Luminex, Japan.

\section{Conflict of Interest}

None.

\section{Grant Support}

This study was supported by a grant from the Japan Sport Council of 2014.

\section{References}

1. Geyer H, Berschick P, Mareck-Engelke U, Schanzer W. DNA typing for the confirmation of manipulation in dope control: a casework. In: Schanzer W, Geyer H, Gotzmann A, Mareck-Engelke U, eds. Recent Advances in Doping Analysis (5). Sport and Buch Strau $\beta$, Cologne, Germany,

Table 10. Detection Limits of the Assay for DNA From Urine Samples Cryopreserved for 1 - 1.5 Years

\begin{tabular}{lllll}
\hline Sample No. & \multicolumn{1}{c}{ MtDNA type } & & Detection limit \\
naplogroup & HV1C & HV2C & 0.005 \\
\hline 1 & A & $5 \mathrm{CT}>10 \mathrm{C}$ & $8 \mathrm{CT}$ & 0.0025 \\
2 & A & $3 \mathrm{CT}$ & $8 \mathrm{CT}$ & 0.005 \\
3 & B & $10 \mathrm{C}>11 \mathrm{C}>9 \mathrm{C}$ & $8 \mathrm{CT}$ & 0.0025 \\
4 & B & $10 \mathrm{C}>11 \mathrm{C}>9 \mathrm{C}$ & $7 \mathrm{CT}$ & 0.005 \\
5 & D4 & $5 \mathrm{CT}$ & Others & 0.0025 \\
6 & D4 & $5 \mathrm{CT}>10 \mathrm{C}$ & $7 \mathrm{CT}$ & 0.005 \\
7 & D5 & $10 \mathrm{C}>11 \mathrm{C}>9 \mathrm{C}$ & $7 \mathrm{CT}>6 \mathrm{CT}$ & 0.0025 \\
\hline 8 & D5 & $10 \mathrm{C}>11 \mathrm{C}>9 \mathrm{C}$ & 6CT $>7 \mathrm{CT}$ & 0.005 \\
\hline
\end{tabular}


1997:301.

2. Junge A, Steevens M, Madea B. Successful DNA typing of a urine sample in a doping control case using human mitochondrial DNA analysis. J Forensic Sci. 2002;47(5):1002-1024.

3. Sipoli Marques MA, Pinto Damasceno LM, Gualberto Pereira HM, Caldeira CM, Pereira Dias BF, de Giacomo Vargens D, Amoedo ND, et al. DNA typing: an accessory evidence in doping control. J Forensic Sci. 2005;50(3):587-592.

4. Robinson N, Castella V, Saudan C, Sottas PE, Schweizer C, Dimo-Simonin N, Mangin P, et al. Elevated and similar urinary testosterone/epitestosterone ratio in all samples of a competition testing: suspicion of a manipulation. Forensic Sci Int. 2006;163(1-2):148-151.

5. Thevis M, Geyer H, Mareck U, Sigmund G, Henke J, Henke L, Schanzer W. Detection of manipulation in doping control urine sample collection: a multidisciplinary approach to determine identical urine samples. Anal Bioanal Chem. 2007;388(7):1539-1543.

6. Johnson DJ, Calderaro AC, Roberts KA. Variation in nuclear DNA concentrations during urination. J Forensic Sci. 2007;52(1):110-113.

7. Prinz M, Grellner W, Schmitt C. DNA typing of urine samples following several years of storage. Int J Legal Med. 1993;106(2):75-79.

8. Vu NT, Chaturvedi AK, Canfield DV. Genotyping for DQA1 and PM loci in urine using PCR-based amplification: effects of sample volume, storage temperature, preservatives, and aging on DNA extraction and typing. Forensic Sci Int. 1999;102(1):23-34.

9. Milde A, Haas-Rochholz H, Kaatsch HJ. Improved DNA typing of human urine by adding EDTA. Int J Legal Med. 1999;112(3):209-210.

10. Soltyszewski I, Pepinski W, Dobrzynska-Tarasiuk A, Janica J. DNA typeability in liquid urine and urine stains using AmpFISTR SGM Plus. Adv Med Sci. 2006;51:3638.

11. Zhang SH, Zhao SM, Zhao ZM, Li CT. Genotyping of urinary samples stored with EDTA for forensic applications. Genet Mol Res. 2012;11(3):3007-3012.

12. Deelman LE, van der Wouden EA, Duin M, Henning RH. A method for the ultra rapid isolation of PCR-ready DNA from urine and buccal swabs. Mol Biol Today. 2002;3:5154.

13. Cannas A, Kalunga G, Green C, Calvo L, Katemangwe P, Reither K, Perkins MD, et al. Implications of storing urinary DNA from different populations for molecular analyses. PLoS One. 2009;4(9):e6985.

14. Aoki K, Tanaka H, Ueki M. DNA typing for personal identification of urine after long-term preservation for testing in doping control. Drug Test Anal. 2017;9(8):1116-1123.

15. Tanaka M, Cabrera VM, Gonzalez AM, Larruga JM, Takeyasu T, Fuku N, Guo LJ, et al. Mitochondrial genome variation in eastern Asia and the peopling of Japan. Genome Res. 2004;14(10A):1832-1850.

16. Tanaka M, Umetsu K. Patent Application Publication No. 2003-274947 (http://www/j-tokkyo.com/2003/C12N/ JP2003-274947.shtml).
17. Parsons TJ, Muniec DS, Sullivan K, Woodyatt N, Alliston-Greiner R, Wilson MR, Berry DL, et al. A high observed substitution rate in the human mitochondrial DNA control region. Nat Genet. 1997;15(4):363-368.

18. Tsutsumi H, Komuro T, Mukoyama R, Nogami H. Hypervariable region structure and polymorphism of mtDNA from dental pulp and a family analysis. J Oral Sci. 2006;48(3):145-152.

19. Lutz S, Weisser HJ, Heizmann J, Pollak S. Mitochondrial heteroplasmy among maternally related individuals. Int J Legal Med. 1999;113(3):155-161.

20. Brandstatter A, Niederstatter H, Parson W. Monitoring the inheritance of heteroplasmy by computer-assisted detection of mixed basecalls in the entire human mitochondrial DNA control region. Int J Legal Med. 2004;118(1):4754.

21. Watanabe G, Umetsu K. The heteroplasmy of mitochondrial DNA polymorphism of mother and child or sibling. Jpn J Forensic Sci Technol. 2007;12(2):153-158.

22. Turchi C, Buscemi L, Pesaresi M, Di Saverio M, Paoli M, Tagliabracci A. Occurrence of heteroplasmy in related individuals. Int Congr Ser. 2003;1239:553-556.

23. Lutz-Bonengel S, Schmidt U, Sanger T, Heinrich M, Schneider PM, Pollak S. Analysis of mitochondrial length heteroplasmy in monozygous and non-monozygous siblings. Int J Legal Med. 2008;122(4):315-321.

24. Stewart JE, Fisher CL, Aagaard PJ, Wilson MR, Isenberg AR, Polanskey D, Pokorak E, et al. Length variation in HV2 of the human mitochondrial DNA control region. J Forensic Sci. 2001;46(4):862-870.

25. Kirches E, Michael M, Warich-Kirches M, Schneider T, Weis S, Krause G, Mawrin C, et al. Heterogeneous tissue distribution of a mitochondrial DNA polymorphism in heteroplasmic subjects without mitochondrial disorders. J Med Genet. 2001;38(5):312-317.

26. Lee HY, Chung U, Park MJ, Yoo JE, Han GR, Shin KJ. Differential distribution of human mitochondrial DNA in somatic tissues and hairs. Ann Hum Genet. 2006;70(Pt 1):59-65.

27. Pfeiffer H, Lutz-Bonengel S, Pollak S, Fimmers R, Baur MP, Brinkmann B. Mitochondrial DNA control region diversity in hairs and body fluids of monozygotic triplets. Int J Legal Med. 2004;118(2):71-74.

28. Lagerstrom-Fermer M, Olsson C, Forsgren L, Syvanen AC. Heteroplasmy of the human mtDNA control region remains constant during life. Am J Hum Genet. 2001;68(5):1299-1301.

29. Itoh Y, Mizuki N, Shimada T, Azuma F, Itakura M, Kashiwase K, Kikkawa E, et al. High-throughput DNA typing of HLA-A, -B, -C, and -DRB1 loci by a PCR-SSOP-Luminex method in the Japanese population. Immunogenetics. 2005; 57(10): 717-729.

30. Fuku N, Park KS, Yamada Y, Nishigaki Y, Cho YM, Matsuo H, Segawa T, et al. Mitochondrial haplogroup N9a confers resistance against type 2 diabetes in Asians. Am J Hum Genet. 2007;80(3):407-415.

31. Nishigaki Y, Ueno H, Coku J, Koga Y, Fujii T, Sahashi K, Nakano K, et al. Extensive screening system using suspension array technology to detect mitochondrial DNA 
point mutations. Mitochondrion. 2010;10(3):300-308.

32. Shinoda K, Kakuda, Doi N. Mitochondrial DNA polymorphism in late Shell midden period skeletal remains excavated from two archaeological sites in Okinawa. Bull Natl Mus Nat Sci Ser D. 2012;38:51-56.

33. Sample protocols for nucleic acid detection using MagPlex-TAG microspheres. Luminex. 2010.

34. Foord AJ, White JR, Colling A, Heine HG. Microsphere suspension array assays for detection and differentiation of Hendra and Nipah viruses. Biomed Res Int. 2013;2013:289295.

35. Andrews RM, Kubacka I, Chinnery PF, Lightowlers RN, Turnbull DM, Howell N. Reanalysis and revision of the Cambridge reference sequence for human mitochondrial DNA. Nat Genet. 1999;23(2):147.

36. Castella V, Dimo-Simonin N, Brandt-Casadevall C, Robinson N, Saugy M, Taroni F, Mangin P. Forensic identification of urine samples: a comparison between nuclear and mitochondrial DNA markers. Int J Legal Med. 2006;120(2):67-72.

37. Nakahara H, Fujii K, Mizuno N, Yoshida K, Kasai K.
Evaluation of DNA quantification methods for forensic biological samples. Jpn J Forensic Sci Technol. 2007;12(1):13-26.

38. Yu Y, Liu H, Ikeda Y, Amiot BP, Rinaldo P, Duncan SA, Nyberg SL. Hepatocyte-like cells differentiated from human induced pluripotent stem cells: relevance to cellular therapies. Stem Cell Res. 2012;9(3):196-207.

39. Maruyama S, Minaguchi K, Saitou N. Sequence polymorphisms of the mitochondrial DNA control region and phylogenetic analysis of mtDNA lineages in the Japanese population. Int J Legal Med. 2003;117(4):218-225.

40. Watkins WS, Bamshad M, Dixon ME, Bhaskara Rao B, Naidu JM, Reddy PG, Prasad BV, et al. Multiple origins of the mtDNA 9-bp deletion in populations of South India. Am J Phys Anthropol. 1999;109(2):147-158.

41. Malik S, Sudoyo H, Pramoonjago P, Suryadi H, Sukarna T, Njunting M, Sahiratmadja E, et al. Nuclear mitochondrial interplay in the modulation of the homopolymeric tract length heteroplasmy in the control (D-loop) region of the mitochondrial DNA. Hum Genet. 2002;110(5):402411. 